\title{
The Influence of Product Innovation and Brand Image on Customer Purchase Decision on Oppo Smartphone Products in South Tangerang City
}

\author{
Ade Yusuf \\ Pamulang University, Banten, Indonesia \\ dosen02604@unpam.ac.id
}

\begin{abstract}
This study aims to determine the effect of product innovation and Brand Image on Consumer Purchase Decisions of OPPO Smartphone Products in South Tangerang City. The method used is explanatory research with analysis techniques using statistical analysis with regression testing, correlation, determination, and hypothesis testing. The results of this study that product innovation has a significant effect on purchasing decisions by $42.1 \%$, hypothesis testing obtained $t$ count> $t$ table or (8.274> 1.986). Brand Image has a significant effect on Purchasing Decision by $37.4 \%$, hypothesis testing is obtained $t$ count> t table or (7.488> 1.986). Product innovation and brand image simultaneously have a significant effect on purchasing decisions with the regression equation $Y=10.355+0.411 X 1+0.340 X 2$ and the contribution of the effect is $50.4 \%$, the hypothesis test is obtained $F$ count $>F$ table or $(47.521>2.770)$.
\end{abstract}

Keywords

product innovation, brand image; purchase decision

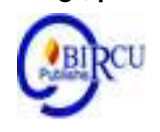

\section{Introduction}

In today's era of digitalization of telecommunications, consumers are faced with a variety of tools and technologies that offer convenience with a variety of very sophisticated and attractive features. Communication technology in the digitalization era is increasingly gaining a place as one of the fastest-growing businesses today, this is of course a challenge and at the same time encourages all technology companies in the world to create products that can meet market needs. This challenge is also supported by the existence of similar companies that offer similar products and characteristics such as the smartphone companies Oppo, Samsung, Xiaomi, Vivo, and Realme.

Along with the development of technology and information, consumers are smarter in choosing a product. One of the factors that consumers consider is product innovation. Product innovation can increase the added value of a product, so this will influence consumers in determining purchasing decisions. Market changes like this require companies to carry out Product Innovation (product innovation) on their products to maintain their survival and gain company profits (Tjiptono, 2008).

In large companies, product innovation has become a sustainable market strategy by market needs to maintain the brand image. But what about the Oppo Smartphone company, whether the marketing strategy through innovation can influence the Oppo smartphone purchase decision sustainably. "Product innovation is a product that is considered new by potential users. It doesn't matter whether the product is new to the world or some other category that is included in the new product". (Lamb and Hair, 2001: 462). 
Apart from product innovation, brand image is also something that consumers consider when making a purchase decision. "Brand image is a very important aspect of the smartphone brand. Brand image is an identity (including symbolic personality, value proposition, brand essence, and brand position). Brand image is how consumers perceive a brand actually, which is an opinion formed by consumers as an interpretation of everything that Aaker and Robinette's companies do in Ismail (2012: 62).

According to Kotler and Armstrong (2008: 282), marketers must be able to put the brand well in the minds of their consumers. Developing a strong brand image is one way to make consumers familiar with the product. This will affect consumer behavior in making choices. From various other well-known brands that are competitors in the product.

The business world which is also growing rapidly by the development and sophistication of technology is the Smartphone company. During its development, Smartphone companies issued many well-known product brands. The Smartphone company that is also developing is the Oppo Smartphone company, which is also one of several Smartphone companies that also dominate the consumer market.

Oppo Smartphone is a product that can be used by all people. In introducing their products, the Oppo Smartphone company uses a marketing strategy by inviting Indonesian artists, in this case, the Oppo Smartphone company, to use Raisa, Chealse Island, and Isyana as brand ambassadors for the oppo smartphone company's products. Brand ambassadors are the faces of the companies they represent. The brand ambassador introduced by the Oppo Smartphone company is one of the market strategies carried out by companies so that the products they introduce can easily be embedded in the minds of consumers like their product identities.

Purchasing decisions are the process of consumers choosing or determining to buy a product or service. "The decision-making process to purchase can be divided into five stages, namely recognizing needs, seeking information, evaluating alternatives, making decisions, evaluating post-purchases." (Suryani, 2012: 17). With a good brand image and product innovation, it is hoped that it can increase consumer confidence in making decisions to buy oppo products. The following is data on sales of oppo smartphones throughout Indonesia in Q2 for the last 3 years according to Indonesia Top smartphone companies (YOY):

Table 1. Indonesia Top smartphone companiesby (YOY) market share comporation

\begin{tabular}{|r|l|r|r|r|}
\hline \multirow{2}{*}{ No. } & \multirow{2}{*}{ Company } & \multicolumn{1}{c|}{ Q 2' 2019 } & \multicolumn{1}{c|}{ Q 2' 2018 } & \multicolumn{1}{c|}{ Q 2' 2017 } \\
\cline { 3 - 5 } & & Sales Volume & Sales Volume & Sales Volume \\
\hline 1 & Samsung & $24 \%$ & $28 \%$ & $32 \%$ \\
\hline 2 & Vivo & $15 \%$ & $6 \%$ & $3 \%$ \\
\hline 3 & Xiaomi & $19 \%$ & $19 \%$ & $3 \%$ \\
\hline 4 & Oppo & $26 \%$ & $17 \%$ & $24 \%$ \\
\hline 5 & Realme & $7 \%$ & & $\mathbf{3 8 \%}$ \\
\hline & Others & $\mathbf{9 \%}$ & $\mathbf{3 0 \%}$ & $\mathbf{1 0 0 \%}$ \\
\hline & Total & $\mathbf{1 0 0 \%}$ & $\mathbf{1 0 0 \%}$ & \\
\hline
\end{tabular}

Source: Datacom, 2019

In table 1, the latest information from the Gartner market research institute shows the sales of various similar smartphone brands such as Samsung, Vivo, Xiaomi, and Realme. The most popular smartphone produced by South Korea is Samsung. While Oppo, in particular, can be seen from the second quarter (Q2) the last three years (2017-2019) are 
still below Samsung. The data shows that sales of Oppo smartphones in Q2 2017 were sold by $24 \%$, it is known that in 2018 there was a decrease in sales volume of $17 \%$, and in Q2 of the following year, sales increased by $26 \%$ compared to the previous year. There has previously been an increase and sales of Oppo Smartphone products in Indonesia.

Marketing carried out by the company makes business people who sell their product brands also carry out interesting marketing strategies. The marketing offered by every business actor who sells Oppo Smartphone products varies, this is because every business actor has a different planning and operational system. Good marketing not only helps businesses to introduce their product brands easily but also helps sales performance. The products offered are Oppo Smartphone products, they carry out a marketing strategy by providing various kinds of promotions that have been prepared by the Jaya Ponsel store management and provide various interesting things when buying cellphone products. By assessing the influence of product innovation and brand image, it is hoped that it will be able to find out the effect on purchasing decisions for Oppo smartphones on consumers in South Tangerang City.

Based on the explanation of this background, the authors are interested in conducting research entitled "The Effect of Product Innovation and Brand Image on Purchasing Decisions of OPPO Smartphone Products for Consumers in South Tangerang City"

\section{Review of Literatures}

\subsection{Product Innovation}

From the explanation of the opinions of the experts above, it can be concluded that the definition of product innovation is a series of various functional processes that influence one another, to adapt to a dynamic environment. Therefore, companies are required to be able to create new thoughts, new ideas. Product innovation can also be in the form of changes in design, components, and product architecture, in offering innovative products and improving services that create and satisfy customers in achieving success.

Hurley and Hult (1998: 45) defines product innovation as a company mechanism to adapt to a dynamic environment, therefore companies are required to be able to create new thoughts, new ideas and offer innovative products and improve satisfying services customer. The development of business organizations depends on the quality of the products they produce. The better the product produced and useful, the more consumers will enjoy it, especially to meet their daily needs (Romdonny and Rosmadi, 2019).

\subsection{Brand Image}

Brand image is what forms the basis of brand success (Keller, 1993). In the brand image conceptualized in terms of brand association, brand business scenario, a brand image forms the basis for making better performance, brand image, consumer judgment, and consumer strategic marketing decisions about targeting specific markets whose feelings are formed in the minds of customers. Brand image is one of the key elements of brand equity in successful brand management (Aaker, 1991).

\subsection{Purchase Decisions}

Purchasing decisions are thoughts in which individuals evaluate various options and make choices on a product from the many choices. The purchasing decision process is seen as an activity that consists of selecting, obtaining, and evaluating (Rossiter, 2003). Marketing and environmental stimuli enter consumer characteristics and the purchasing decision process Kotler et al., (1999). It is through consumption and product value to 
consumers that reflect social and environmental influences can influence the need for compliance and create purchasing behavior (Kim et al., 2002). The following is the definition of buying decisions according to experts:

\section{Research Methods}

The population in this study amounted to 96 consumers in South Tangerang City. The sample in this study amounted to 96 respondents. The type of research used is associative, where the aim is to determine the effect of the independent variable on the dependent variable either partially or simultaneously. In analyzing the data used instrument test, classical assumption test, regression, coefficient of determination, and hypothesis testing.

\section{Results and Discussion}

\subsection{Descriptive Analysis}

In this test, it is used to determine the minimum and maximum score, the mean score, and the standard deviation of each variable. The results are as follows:

Descriptive Statistics Analysis Results Table

Table 2. Descriptive Statistics

\begin{tabular}{lr|r|r|r|r} 
& N & Minimum & Maximum & Mean & \multicolumn{1}{l}{ Std. Deviation } \\
\hline Product innovation (X1) & 96 & 32 & 48 & 38.50 & 3.786 \\
\hline Brand Image (X2) & 96 & 30 & 46 & 38.33 & 3.644 \\
\hline Purchase Decisions (Y) & 96 & 32 & 46 & 39.20 & 3.505 \\
\hline Valid N (listwise) & 96 & & & & \\
\hline
\end{tabular}

The product innovation obtained a minimum variance of 32 and a maximum variance of 48 with a mean score of 38.50 with a standard deviation of 3.786 .

Brand Image obtained a minimum variance of 30 and a maximum variance of 46 with a mean score of 38.33 with a standard deviation of 3.644 .

The purchase decision obtained a minimum variance of 32 and a maximum variance of 46 with a mean score of 39.20 with a standard deviation of 3.505 .

\subsection{Verification Analysis}

This analysis aims to determine the effect of the independent variable on the dependent variable. The test results are as follows:

\section{a. Multiple Linear Regression Analysis}

This regression test is intended to determine changes in the dependent variable if the independent variable changes. The test results are as follows:

Table 3. Multiple Linear Regression Test Results

\section{Coefficients $^{\mathrm{a}}$}

Unstandardized

Coefficients

Standardized

Coefficients

\begin{tabular}{|c|c|c|c|c|c|}
\hline Model & B & Std. Error & Beta & $\mathrm{t}$ & Sig. \\
\hline (Constant) & 10.355 & 2.990 & & 3.463 & .001 \\
\hline Product innovation (X1) & .411 & .083 & .444 & 4.945 & .000 \\
\hline Brand Image (X2) & .340 & 086 & .353 & 3.935 & .000 \\
\hline
\end{tabular}

a. Dependent Variable: Keputusan Pembelian (Y) 
Based on the test results in the table above, the regression equation $\mathrm{Y}=10.355+$ $0.411 \mathrm{X} 1+0.340 \mathrm{X} 2$ is obtained. From this equation it is explained as follows:

1) A constant of 10,355 means that if there is no product innovation and brand image, then there is a purchase decision value of 10,355 points.

2) The product innovation regression coefficient is 0.411 , this figure is positive, meaning that every time there is an increase in product innovation of 0.411 , the Purchase Decision will also increase by 0.411 points.

3) The Brand Image regression coefficient is 0.340, this number is positive, meaning that every time there is an increase in Brand Image of 0.340, the Purchase Decision will also increase by 0.340 points.

\section{b. Correlation Coefficient Analysis}

Correlation coefficient analysis is intended to determine the level of strength of the relationship between the independent variable and the dependent variable either partially or simultaneously. The test results are as follows:

Table 4. Results of Testing the Correlation Coefficient of Product Innovation on Purchasing Decisions

\begin{tabular}{|c|c|c|c|}
\hline & Correlation & & \\
\hline & & $\begin{array}{c}\text { Product } \\
\text { innovation }(\mathrm{X} 1)\end{array}$ & $\begin{array}{c}\text { Purchase } \\
\text { Decisions (Y) }\end{array}$ \\
\hline Product innovation (X1) & Pearson Correlation & 1 & $.649^{* *}$ \\
\hline & Sig. (2-tailed) & & .000 \\
\hline Purchase Decisions (Y) & Pearson Correlation & $.649^{* *}$ & 1 \\
\hline & Sig. (2-tailed) & .000 & \\
\hline
\end{tabular}

Based on the test results obtained a correlation value of 0.649 means that product innovation has a strong relationship with Purchasing Decisions.

Table 5. Testing Results of Brand Image Correlation Coefficients Against Purchasing

\begin{tabular}{|c|c|c|c|}
\hline & $\begin{array}{r}\text { Decisior } \\
\text { Correlatio }\end{array}$ & & \\
\hline & & $\begin{array}{l}\text { Brand Image } \\
\text { (X2) }\end{array}$ & $\begin{array}{c}\text { Purchase } \\
\text { Decisions (Y) }\end{array}$ \\
\hline$\overline{\text { Brand Image (X2) }}$ & Pearson Correlation & 1 & $.611^{* *}$ \\
\hline & Sig. (2-tailed) & & .000 \\
\hline Purchase Decisions (Y) & Pearson Correlation & $.611^{* *}$ & \\
\hline & Sig. (2-tailed) & .000 & \\
\hline
\end{tabular}

Based on the test results obtained a correlation value of 0.611 means that Brand Image has a strong relationship with Purchasing Decisions.

Table 6. Test Results Correlation Coefficient of Product Innovation and Brand Image Simultaneously to Purchasing Decisions

\section{Model Summary}

\begin{tabular}{l|l|l|l|ll} 
Model & R & R Square & $\begin{array}{c}\text { Adjusted R } \\
\text { Square }\end{array}$ & \multicolumn{2}{c}{$\begin{array}{c}\text { Std. Error of the } \\
\text { Estimate }\end{array}$} \\
\hline 1 & $.710^{\mathrm{a}}$ & .504 & .493 & 2.495 \\
\hline
\end{tabular}

a. Predictors: (Constant), Brand Image (X2), Product innovation (X1) 
Based on the test results obtained a correlation value of 0.710 means that product innovation and Brand Image simultaneously have a strong relationship with Purchasing Decisions.

\section{c. Analysis of the Coefficient of Determination}

The analysis of the coefficient of determination is intended to determine the percentage of influence of the independent variable on the dependent variable, either partially or simultaneously. The test results are as follows:

Table 7. Results of Testing the Coefficient of Determination of Product Innovation on Purchasing Decisions

\section{Model Summary}

\begin{tabular}{|c|c|c|c|c|}
\hline \multicolumn{5}{|c|}{ maty } \\
\hline Model & $\mathrm{R}$ & R Square & $\begin{array}{l}\text { Adjusted R } \\
\text { Square }\end{array}$ & $\begin{array}{l}\text { Std. Error of the } \\
\text { Estimate }\end{array}$ \\
\hline & $.649^{a}$ & .421 & .41 & 2.68 \\
\hline
\end{tabular}

a. Predictors: (Constant), Product innovation (X1)

Based on the test results, it was obtained a determination value of 0.421 , meaning that product innovation had a $42.1 \%$ influence on the Purchasing Decision.

Table 8. The Results of Testing the Brand Image Determination Coefficient on Purchasing Decisions

\section{Model Summary}

\begin{tabular}{lrr|rr|r} 
Model & R & & R Square & $\begin{array}{c}\text { Adjusted R } \\
\text { Square }\end{array}$ & $\begin{array}{c}\text { Std. Error of the } \\
\text { Estimate }\end{array}$ \\
\hline 1 & $.611^{\mathrm{a}}$ & .374 & .367 & 2.789 \\
\hline
\end{tabular}

a. Predictors: (Constant), Brand Image (X2)

Based on the test results obtained a determination value of 0.374 meaning that the Brand Image has an influence contribution of $37.4 \%$ to the Purchase Decision.

Table 9. Test Results of Product Innovation Determination Coefficient and Brand Image against Purchasing Decisions

\section{Model Summary}

\begin{tabular}{|c|c|c|c|c|}
\hline \multicolumn{5}{|c|}{ Imat } \\
\hline Model & $\mathrm{R}$ & R Square & $\begin{array}{l}\text { Adjusted R } \\
\text { Square }\end{array}$ & $\begin{array}{l}\text { Std. Error of the } \\
\text { Estimate }\end{array}$ \\
\hline 1 & $.710^{\mathrm{a}}$ & .504 & .49 & 2.49 \\
\hline
\end{tabular}

a. Predictors: (Constant), Brand Image (X2), Product innovation (X1)

Based on the test results obtained a determination value of 0.504 means that product innovation and Brand Image simultaneously have an influence contribution of $50.4 \%$ on the Purchase Decision, while the remaining $49.6 \%$ is influenced by other factors.

\section{d. Hypothesis Testing}

\section{Partial Hypothesis Test (t-test)}

Hypothesis testing with the t-test is used to determine which partial hypothesis is accepted. The first hypothesis: There is a significant influence between product innovation on purchasing decisions. 
Table 10. Hypothesis Test Results for Product Innovation on Purchasing Decisions

\section{Coefficients $^{\mathrm{a}}$}

\begin{tabular}{|c|c|c|c|c|c|}
\hline \multirow[b]{2}{*}{ Model } & \multicolumn{2}{|c|}{$\begin{array}{l}\text { Unstandardized } \\
\text { Coefficients }\end{array}$} & \multirow{2}{*}{$\begin{array}{c}\text { Standardized } \\
\text { Coefficients } \\
\text { Beta }\end{array}$} & \multirow[b]{2}{*}{$\mathrm{t}$} & \multirow[b]{2}{*}{ Sig. } \\
\hline & $\mathrm{B}$ & Std. Error & & & \\
\hline 1 (Constant) & 16.061 & 2.810 & & 5.717 & .000 \\
\hline $\begin{array}{l}\text { Product Innovation } \\
\text { (X1) }\end{array}$ & .601 & .073 & .649 & 8.274 & .000 \\
\hline
\end{tabular}

a. Dependent Variable: Purchasing Decisions (Y)

Based on the test results in the table above, the value of $t$ count $>t$ table or (8.274>1.986) is obtained, thus the first hypothesis that there is a significant effect between product innovation on purchasing decisions is accepted.

Table 11. Hypothesis Test Results for Brand Image against Purchasing Decisions

\section{Coefficients $^{\mathrm{a}}$}

Unstandardized

Coefficients

\section{Standardized}

Coefficients

\begin{tabular}{|c|c|c|c|c|c|}
\hline Model & B & Std. Error & Beta & $\mathrm{t}$ & Sig. \\
\hline 1 (Constant) & 16.658 & 3.024 & & 5.509 & .000 \\
\hline Brand Image (X2) & .588 & .079 & .611 & 7.488 & .000 \\
\hline
\end{tabular}

a. Dependent Variable: Purchasing Decisions (Y)

Based on the test results in the table above, the value of $t$ count $>t$ table or $(7,488>$ $1,986)$ is obtained, thus the second hypothesis that is proposed is that there is a significant effect between Brand Image on Purchasing Decisions.

\section{Simultaneous Hypothesis Test (Test F)}

Hypothesis testing with the $\mathrm{F}$ test is used to determine which simultaneous hypothesis is accepted. The third hypothesis there is a significant influence between product innovation and Brand Image on Purchasing Decisions.

Table 12. Hypothesis Test Results from Product Innovation and Brand Image against

Purchasing Decisions

$$
\text { ANOVA }^{\mathrm{a}}
$$

\begin{tabular}{llr|r|r|r|r} 
Model & & Sum of Squares & df & Mean Square & F & Sig. \\
\hline 1 & Regression & 588.296 & 2 & 294.148 & 47.251 & $.000^{b}$ \\
\cline { 2 - 7 } & Residual & 578.943 & 93 & 6.225 & \\
\cline { 2 - 7 } & Total & 1167.240 & 95 & & & \\
\hline
\end{tabular}

Based on the test results in the table above, the calculated $\mathrm{F}$ value> $\mathrm{F}$ table or (47.521> 2.770), thus the third hypothesis proposed that there is a significant effect between product innovation and Brand Image on Purchasing Decisions is accepted.

\subsection{The Effect of Product Innovation on Purchasing Decisions}

Product innovation has a significant effect on purchasing decisions with a correlation of 0.649 or has a strong relationship with an influential contribution of $42.1 \%$. Hypothesis testing obtained $t$ value $>t$ table or $(8.274>1.986)$. Thus the first hypothesis proposed that there is a significant effect between product innovation on Purchasing Decisions is accepted. 


\subsection{The Influence of Brand Image on Purchasing Decisions}

Brand Image has a significant effect on purchasing decisions with a correlation of 0.611 or has a strong relationship with a contribution of influence of $37.4 \%$. Hypothesis testing obtained the value of $t$ count $>t$ table or $(7,488>1,986)$. Thus, the second hypothesis proposed that there is a significant effect between Brand Image and Purchase Decision is accepted.

\subsection{The Influence of Product Innovation and Brand Image on Purchasing Decisions}

Product innovation and brand image have a significant effect on purchasing decisions by obtaining the regression equation $\mathrm{Y}=10.355+0.411 \mathrm{X} 1+0.340 \mathrm{X} 2$, the correlation value is 0.710 or has a strong relationship with the contribution of influence of $50.4 \%$ while the remaining $49.6 \%$ is influenced by factors other. Hypothesis testing obtained the value of $\mathrm{F}$ count $>\mathrm{F}$ table or $(47.521>2.770)$. Thus the third hypothesis proposed that there is a significant effect between product innovation and Brand Image on Purchasing Decisions is accepted.

\section{Conclusion}

Product innovation has a significant effect on purchasing decisions with a contribution of influence of $42.1 \%$. Hypothesis testing obtained the value of $t$ count $>t$ table or (8.274> 1.986).

Brand Image has a significant effect on Purchasing Decisions with a contribution of influence of $37.4 \%$. Hypothesis test obtained $t$ value $>t$ table or $(7,488>1,986)$.

Product innovation and brand image have a significant effect on purchasing decisions with a contribution of influence of $50.4 \%$ while the remaining $49.6 \%$ is influenced by other factors. Hypothesis testing obtained the value of $F$ count $>\mathrm{F}$ table or $(47,521>2,770)$.

\section{Suggestions}

1. Companies need to improve Product Innovation, such as increasing product variations, better product quality to increase Purchasing Decisions on Oppo Smartphone Product Consumers for Consumers in the city of South Tangerang.

2. It is better if owners can be more active in finding and understanding what consumers want to improve more effective purchasing decisions.

3. The results show that the variable product innovation and Brand Image have various responses from respondents and some are not satisfied because the entrepreneurs do not do activities that can stimulate consumer interest, such as carrying out activities that support marketing performance in the company, especially Product Innovation, more satisfying product quality, and service. It is suggested that employers can introduce work programs and work completeness patterns by making regular observations.

4. It is suggested for further researchers, especially the same research, to be considered for other factors outside the Product Innovation and Brand Image variables towards Purchasing Decisions and can increase sales at the company so that it will generate more sales and become a reference for further better research. 


\section{References}

Algifari. (2015). "Regression Analysis for Business and Economics". Yogyakarta: BPFE. Anjani, R. (2019). Financial Administration Governance, and Development of Seaside Village, North Bengkulu Regency. Journal of the Rafflesia Earth Community Service, 2 (2).

Arikunto, Suharsimi (2014). "Research Procedure, A Practice Approach". Jakarta: Rineka Cipta.

Ariyanto, A., Nuryani, A., \& Sunarsi, D. (2020). The Influence of Store Atmosphere and Promotion on Purchasing Decisions at Alfamart BSD, South Tangerang. Journal of Effective Economics, 3 (1).

Asmawi, M. (2017). The effect of compensation, empowerment, and job satisfaction on employee loyalty. International Journal of Scientific Research and Management, 5 (12), 7590-7599.

Candra Dery Bagus, et al. "The Effect of Product Innovation and Brand Image on Purchasing Decisions at Olivia Cake" Journal of Applications and Business. E-ISSN: 2407-5523, p. 86-91

D Sunarsi, A Barsah, H Hastono, IR Akbar (2020). The Influence of Prices and Facilities on the Interest of Boarding Rentals which Affects Student Achievement in Yogyakarta. Journal of Education, Humanities and Social Sciences (JEHSS) 3 (2), 601-609

Ghozali, Imam, 2011. "Application of Multivariate Analysis with the SPSS Program".

Gifani Auliannisa, Syahputra. 2017. "The Influence of Brand Image on Purchasing Decisions of Oppo Smartphone Products for Telkom University Students" Journal of Business and Science and Technology. Vol. 10 No.2, p. 82-92

Gumilang, Ratna Risa. 2019. "Implementation of Digital Marketing

Hanaysha, Jalal, Haim Hilman, Noor Hasmini Abdul-Ghani. 2014. " Direct and Indirect Effects of Product Innovation and Product Quality on Brand Image: Empirical Evidence from the Automotive Industry "International Journal of Scientific Publications and Research. Business Management Vol.4. Issue 11, pp. 2-5

Haque, MG., Munawaroh, Sunarsi, D., (2020). Analysis of SMEs Culinary Marketing Strategy During Covid 19 Pandemic: A Study at "Sate Bebek Cilegon" Resto in Cilegon, Banten. International Journal of Education, Information Technology, and Others. Vol. 3. Issue 2

Indah, Rasyid, Tri. 2018. "The Influence of Product Innovation and Prices on Motorcycle Purchase Decisions in the City of South Tangerang" Perspective Journal. Vol. 16 No.1, p. 40-49

Physical, J. (2019). The Effect of Market Orientation and Product Innovation on Competitive Advantage at PT. Variety of Nusantara Steel. Business Disruption, 2 (1).

Jasmani, Jasmani, and Denok Sunarsi. "The Influence of Product Mix, Promotion Mix, and Brand Image on Consumer Purchasing Decisions of Sari Roti Products in South Tangerang." PINISI Discretion Review 1.1 (2020): 165-174.

Keller and Armstrong (2017) "Marketing Principles". Twelfth Edition ”. Volume One. Jakarta: Erlangga.

Kevin Keller and Armstrong (2017) Marketing Principles, Twelfth Edition, Volume One, Jakarta: Erlangga.

Kharis, Ismu Fadli (2011). "Study Regarding Impulse Buying in Online Sales". Semarang: Thesis, Diponegoro University 
Kotler \& Keller (2016) "Marketing Management". PT. Macaman Jaya Cemerlang. Jakarta. Kotler (2016) "Marketing Management". Fourteenth Edition, Jakarta: PT. Index.

Lupiyadi, Rambat (2016) Service Marketing Management 2nd edition, Jakarta: Salemba Empat.

Lupiyoadi (2016) Service Marketing Management, 4th Edition, Jakarta: Salemba Empat.

Mani, J. (2017). The Effect of Brand Perception and Service Quality on Customer Satisfaction (Case Study at PT. Bisma Narendra in Jakarta). Independent Journal, 1 (2), 187-206.

Marheni Eka Saputri, Tutut Ratna Pranata. 2014. "The Influence of Brand Image on the Loyalty of Ipohone Smartphone Users" Journal of the Faculty of Communication and Business. Vol.13 No.3, p. 191-201

Nasir, Akhmad. 2018. "The Effect of Product Innovation on the Marketing Performance of the Furniture Industry in Pasuruan Regency". Scientific research, "Journal of Management Science and Accounting Vol.6 No.2, Hal. 18-20

Onsardi, O. (2018). Employee Loyalty at Private Universities in Bengkulu City. COSTING: Journal of Economic, Business and Accounting, 2 (1), 1-13.

Onsardi, O. (2019). The Effect of Compensation and Empowerment on Employee Loyalty with Intervening Variables of Job Satisfaction (No. jsypg). Center for Open Science.

Robins, Coulter. 2010. Management. Jakarta Erlangga.

Romdonny, J., and Rosmadi, M.L.N. (2019). Factors Affecting Customer Loyalty in Products. Budapest International Research and Critics Institute-Journal (BIRCIJournal). P. 337-343.

Sedarmayanti. (2011). Research methodology. Bandung: Munandar Maju. Pious, Rifki. 2017. "The Influence of Lifestyle Product Innovations, Prices on Purchasing Decisions of Stalker Pomade Hair Oil in Un Kediri" Journal of Management Economics. Vol.1 No.1, p. 2-12

Semarang: Diponegoro University Publishing Agency

Suhaily, Lily, and Syarief Darmoyo. 2017. "The Effect of Product Quality, Perceived Price and Brand Image on Purchasing Decisions Gained Customer Trust (Studies on Japanese Brand Electronic Products)" Journal of the Faculty of Economics and Business. Vol. 21 No. 22, p. 5

Tambunan, Elisabet and Marupa Siregar. 2018. "The Influence of Product Promotion and Innovation on Purchasing Decisions of Azzahra Batik Medan" Mutiara Manajemen Journal. Vol.3 No.1, p. 3-9

Wulandari, Dwi Ajeng, and Farah Oktafani. 2017. "The Influence of Brand Image on the Purchase Decision Process of Nike Shoes for Communication and Business Students of Telkom University Bandung" Journal of Economics and Business. Vol. No.1, pg. 50-58

Yusuf, A., \& Sunarsi, D. (2020). The Effect of Promotion and Price on Purchase Decisions. Almana: Journal of Management and Business, 4 (2), 272-279. 